\title{
The Folly Of Making EPS Comparisons Across Companies: Do Accounting Textbooks Send The Correct Message?
}

Timothy P. Kelley, (Email: tkelley@sandiego.edu), University of San Diego Judith A. Hora, (Email: jhora@sandiego.edu), University of San Diego

\begin{abstract}
This paper demonstrates why EPS comparisons across companies are meaningless. An example is provided showing how a company with a higher ROE than another company may have a lower EPS simply from having a lower book value per share (and more shares outstanding) than the comparison company. While ROE comparisons across companies can be useful, cross-company EPS comparisons are meaningless due to the arbitrary number of shares outstanding across companies. The authors review the EPS discussion of 31 financial and intermediate accounting textbooks aimed at US students and find that six of these textbooks incorrectly assert or imply that cross-company EPS comparisons are meaningful. Over 50\% of the textbooks reviewed provide no warning that cross-company EPS comparisons should be avoided.
\end{abstract}

Keywords: Accounting Education, Earnings per Share, EPS, Return on Equity, ROE.

\section{INTRODUCTION}

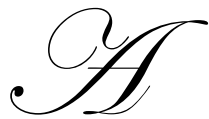

ccounting textbooks have increasingly emphasized the use of accounting information and have put less emphasis on procedural matters. Since users of accounting information are interested in earnings per share (EPS) figures, more textbooks are discussing how EPS can be used in making investment decisions instead of simply showing how EPS is calculated.

In our study, we reviewed Principles of Financial Accounting, MBA Financial Accounting, and Intermediate Accounting textbooks aimed at US students with respect to their discussion of EPS, and examined whether or not textbooks warn students that EPS cannot be compared across companies. In the following sections we discuss:

- Why EPS figures cannot be compared across companies, and

- $\quad$ The results of our textbook review to determine the extent that textbooks warn students about improper cross-company EPS comparisons.

\section{AVOIDING CROSS-COMPANY EPS COMPARISONS}

EPS figures cannot be meaningfully compared across companies since the number of shares outstanding for each company is arbitrary. This is not to say that EPS figures are not important (for example, EPS figures can be used to compare one company's performance over time). In fact, students learn in their intermediate accounting course that companies will retroactively adjust historical EPS information whenever stock splits and/or stock dividends are declared, so that meaningful comparisons of one company's performance over time can be made. With this adjusted historical EPS information, EPS growth rates (but not the raw EPS figures themselves) can be fairly compared across companies. For example, a company with a 15\% EPS growth rate can be said to be doing better than a company with a $4 \%$ EPS growth rate. 
Additionally, EPS is useful as the denominator of the P/E Ratio. However, since the numerator of the P/E ratio (fair market value per share) and the denominator (EPS) are both on a per share basis, the number of shares outstanding across companies is not relevant. In effect, the P/E ratio could be computed as follows: Market Capitalization divided by Net Income. In this method of calculation, the number of shares outstanding is not used. In the same way, ROE (net income divided by stockholders' equity) is not impacted by the number of shares outstanding and can be meaningfully compared across companies.

By contrast, EPS comparisons across companies should be avoided as the denominator in the ratio (number of common shares) is arbitrary for each company. Let's look at an example to illustrate this point. Let's say that Company A has $\$ 2,500,000$ in net income and 1,000,000 common shares outstanding to arrive at $\$ 2.50$ in EPS and Company B has $\$ 1,500,000$ in net income and 200,000 common shares outstanding to arrive at $\$ 7.50$ in EPS. Should we be impressed with Company B's larger EPS? Not necessarily; we need more information!

Specifically, we need to know the amount of stockholders' equity for both companies in order to determine each company's ROE. Let's say that the stockholders' equity for Company A is $\$ 10,000,000$ and that the stockholders' equity for Company B is $\$ 30,000,000$. If this is the case, Company A has a very impressive ROE of $25 \%(\$ 2,500,000$ net income divided by $\$ 10,000,000$ in stockholders' equity). On the other hand, Company B has a less impressive 5\% ROE ( $\$ 1,500,000$ net income divided by $\$ 30,000,000$ in stockholders' equity). How could Company A have one-third the EPS of Company B and five times greater ROE than Company B?

The answer is that each company has significantly different book values per share. While Company A has a book value per share of $\$ 10$ (\$10,000,000 stockholders' equity/1,000,000 common shares outstanding), Company B has a book value per share of $\$ 150$ (\$30,000,000 stockholders' equity/200,000 common shares outstanding). See the reconciliation of EPS, book value per share, and ROE below.

Reconciliation of ROE to EPS

\begin{tabular}{|c|c|c|c|c|c|}
\hline & ROE & $*$ & Book Value/Share & $=$ & EPS \\
\hline & $\begin{array}{c}\text { Net Income } \\
\text { Stockholders'Equity }\end{array}$ & $*$ & $\frac{\text { Stockholders' Equity }}{\text { \# of Common Shares }}$ & $=$ & $\begin{array}{c}\text { Net Income } \\
\text { \# of Common Shares }\end{array}$ \\
\hline Company A & $25 \%$ & $*$ & $\$ 10$ & $=$ & $\$ 2.50$ \\
\hline Company B & $5 \%$ & $*$ & $\$ 150$ & $=$ & $\$ 7.50$ \\
\hline
\end{tabular}

\section{Summary Of Calculations}

ROE

\begin{tabular}{|c|c|c|}
\hline & Company A & Company B \\
\hline Net Income & $\frac{\$ 2,500,000}{=25 \%}$ & $\frac{\$ 1,500,000=5 \%}{\$ 30,000,000}$ \\
\hline Stockholders' Equity & $\$ 10,000,000$ & \\
\hline
\end{tabular}

Book Value per Share

\begin{tabular}{|c|c|c|}
\hline & Company A & Company B \\
\hline Stockholders' Equity & $\frac{\$ 10,000,000}{1,000,000 \text { shares }} \$ 10$ & $\frac{\$ 30,000,000}{200,000 \text { shares }}$ \\
\hline \# of Common Shares & $\$ 150$ \\
\hline
\end{tabular}

EPS

\begin{tabular}{|c|c|c|}
\hline & Company A & Company B \\
\hline \# of $\overline{\text { Cet Income }}$ & $\frac{\$ 2,500,000}{1,000,000}=\$ 2.50$ & $\frac{\$ 1,500,000}{200,000}=\$ 7.50$ \\
shares
\end{tabular}


The example above illustrates that EPS comparisons should not be made across companies. Company B has a greater EPS than Company A simply because Company B has fewer common shares outstanding and a higher book value per share. EPS has dollars of income in the numerator divided by an arbitrary number of common shares outstanding in the denominator, making inter-company comparisons meaningless. By contrast, the ROE metric can be compared across companies because both the numerator and the denominator of this ratio are expressed in dollars.

EPS is clearly a ratio that should not be used to compare across different companies. One would hope that accounting textbooks would highlight this fact with the recent increased focus on financial statement analysis in these textbooks. Unfortunately, with the exception of textbooks aimed at the MBA market, we found few textbooks that warn students to avoid cross-company EPS comparisons.

\section{TEXTBOOK REVIEW}

We reviewed the discussion of EPS in 31 recently published financial accounting and intermediate accounting textbooks aimed at US students and found that over 50\% of these textbooks were silent on the folly of comparing EPS figures across companies. In addition, six of these textbooks either asserted or seemed to imply that such comparisons are useful.

The motivation for the study comes from our observation that (while accounting textbooks do a generally favorable job discussing the usefulness of ratios like ROE and how this ratio can be used to compare across companies), many accounting textbooks still limit their discussion of EPS to procedural and calculation issues. This is seen most frequently in intermediate accounting textbooks, which have elaborate discussions on the various calculations needed to compute diluted EPS. When accounting textbooks venture beyond procedural issues with EPS, some of these discussions could possibly lead students to incorrectly conclude that using EPS figures to compare across companies has value in the decision-making process.

We organized our review into three sections: (1) financial accounting textbooks primarily used to teach principles of financial accounting at the undergraduate level, (2) MBA level financial accounting textbooks, and (3) intermediate accounting textbooks. While some textbooks will say in their preface that they are aimed for both undergraduates and graduates, we grouped each textbook into the category that we believed most appropriately reflected the textbook's primary market.

\section{Financial Accounting Textbooks}

We found six financial accounting textbooks that suggest or imply that EPS comparisons across companies are useful (without providing any warning or caution about cross-company EPS comparisons). For example, Harrison and Horngren (2006, page 385) assert that: "Earnings per share (EPS) is the amount of a company's net income for each share of its stock. EPS is perhaps the single most important statistic used to evaluate companies because it is a standard measure of operating performance of companies of different sizes and different industries." This discussion is unfortunate as it implies that EPS figures can be meaningfully compared across companies.

Albrecht, Stice, Stice, and Skousen (2005) make the same mistake and directly assert that EPS comparisons are feasible across companies. On page 432, Albrecht et al. (2005) state that, "Earnings per share amounts are important because they allow potential investors to compare the profitability of all firms, whether large or small."

Ainsworth and Deines (2004) take matters a step further by not only asserting that EPS comparisons are useful across companies but they also point out on page 579 that Dreyer's has a greater EPS than Yocream and Tofutti and a lower EPS than Anheuser-Busch and McDonalds. Ainsworth and Deines (2004) suggest on page 481 that EPS is a useful metric since it, "allows financial statement users to compare the operating performance of large and small corporations on a per share basis." As we have noted, since the number of shares outstanding for each company is rather arbitrary these EPS comparisons should be avoided. 
A popular financial accounting textbook primarily aimed at the undergraduate market by Needles and Powers (2007, page 623) asserts that, "Readers of financial statements use earnings per share to judge a company's performance and to compare it with the performance of other companies." What are students to conclude from reading these misleading comments from otherwise outstanding textbooks? They can only conclude that crosscompany EPS comparisons are useful, when in fact they should be avoided.

In another financial accounting textbook by Reimers (2003, page 429), the author provides a table to show the EPS figures (and other ratios) for two companies side-by-side without providing readers with a warning that they should not compare the EPS figures of the two companies. Reimers (2003, page 429) shows a table with five ratios comparing the 1999 financial health of Lucent Technology and Sherwin Williams, and the first ratio in the table is EPS (Lucent Technology had an EPS of \$.35 and Sherwin Williams had an EPS of \$1.81). In fairness, Reimers does not suggest that Sherwin Williams is performing better than Lucent based on these relevant ratios, but the author does not provide a warning that such comparisons should be avoided. Instead, Reimers states, "Keep in mind that, with the exception of EPS, the calculations to arrive at a specific ratio may vary from company to company." That said, a student may conclude incorrectly that EPS is the one ratio that can be safely compared across companies. Similarly, Pratt (2006, page 184) shows a table that compares EPS (and 11 other ratios including ROE) across seven companies without providing a warning against making EPS comparisons across companies.

Libby, Libby and Short (2007) also suggest that EPS comparisons across companies may be acceptable. On page 564, Libby et al. (2007) list EPS figures for Outback, Ruby Tuesday, and Wendy's in a table inviting students to compare the relative EPS results for each company. On the following page, Libby et al. (2007) provide "a few cautions" when they assert the following, "While EPS is an effective and widely used measure of profitability, it can be misleading if there are significant differences in the market values of the shares being compared. Two companies earning $\$ 1.50$ per share might appear to be comparable, but if the shares in one company cost $\$ 10$ while the other cost $\$ 175$, they are not comparable." This is a good point and since the fair market values of companies can vary widely, it would appear to be wiser to focus on metrics that can be more safely compared across companies like ROE. It should be noted that on page 253, Libby et al. (2007) does provide a nice comparison of the ROE figures for three companies together with some helpful discussion.

Almost as alarming as the EPS related discussions noted above, we found that over $50 \%$ of the financial accounting textbooks that we reviewed failed to provide any warning that cross-company EPS comparisons should be avoided (Marshall, McManus and Viele (2007), Horngren, Sundem, Elliot, and Philbrick (2005), Wild (2005), Edmonds, Edmonds, McNair, Olds, and Schneider (2006), Werner and Jones (2003), Warren, Reeve, and Fess (2004), Ingram, Albright, and Baldwin (2006), Porter and Norton (2005), Reimers (2005), Philips, Libby and Libby (2006)). At least these financial accounting textbooks did not assert or imply that cross-company EPS comparisons are useful. Instead these textbooks focused on such issues as: (1) the calculation of EPS, (2) the impact of dilutive securities, and (3) noting that EPS becomes the denominator of the P/E ratio. Some of these textbooks do show P/E ratios for various U.S. companies for comparative purposes, which is fair enough since P/E ratios can be compared across companies. Still others, like Reimers (2005) provide a helpful discussion on how the profit comparisons of one company over time are improved by using the EPS metric rather than simply using net income. Philips, Libby and Libby (2006) provide a nice discussion of how treasury stock buybacks can be used to increase (manipulate) EPS. Still, none of these ten textbooks provide students a warning that EPS figures should not be compared across companies.

Solomon (2004) avoids the mistakes of the previously mentioned authors by stating on page 785 that, "comparisons of earnings per share are generally less useful because companies have different numbers of shares outstanding, and these differences are seldom relevant in their evaluation." Still, Solomon (2004, page 785), a bit awkwardly, then compares the EPS figures for The Gap and The Limited leaving students with an ambiguous picture.

We found another financial accounting textbook aimed at the undergraduate market that warns about the folly of EPS comparisons across companies. Kimmel, Weygandt, and Kieso (2007, page 678) state that, "Industry data for earnings per share are not reported, and in fact the Kellogg and General Mills ratios should not be 
compared. Such comparisons are not meaningful because of the wide variations in the number of shares of outstanding stock among companies." Interestingly, even Kimmel et al. (2007) stumble when they invite students on page 94 (in a homework exercise entitled "BYP2-2") to compare the EPS figures for Tootsie Roll and Hershey. The textbook solution manual shows the EPS figures for the two companies without any caution about the potential problems associated with trying to compare the EPS figures across companies.

\section{MBA Financial Accounting Textbooks}

All the MBA level financial accounting textbooks that we reviewed avoid the mistake of encouraging students to compare EPS figures across companies. In fact, some of these textbooks are very helpful in explaining why EPS figures should not be compared across companies.

For example, Stickney and Weil (2006, page 250) warn students about comparing EPS figures across companies noting that they are of "limited use." Stickney and Weil (2006, page 250) expand on this point by explaining that, "two companies could have the same ROE and one firm may have a lower EPS simply because it has a larger number of shares outstanding."

Another MBA level financial accounting textbook by Easton, Wild, and Halsey (2006, page 4-27) provides an excellent warning about the folly of EPS comparisons when it asserts that:

EPS figures are often used as a method of comparing operating results for companies of different sizes under the assumption that the number of shares outstanding is proportional to the income level (that is, a company twice the size of another will report double the income and will double the common shares outstanding, leaving EPS approximately equal for the two companies). This assumption is erroneous. Management controls the number of shares outstanding. Different companies have different philosophies regarding share issuance and repurchase. For example, consider that most companies report annual EPS of less than \$5, while Berkshire Hathaway reported EPS of $\$ 5,308$ for 2003. This is because Berkshire Hathaway has so few shares outstanding, not necessarily because it has stellar profits.

This same example using Berkshire Hathaway is highlighted in a textbook by Dyckman, Easton, and Pfeiffer (2007, page 486) which is aimed at both undergraduate and graduate students according to the book's preface.

Another MBA level financial accounting textbook (ideally suited for an MBA intermediate accounting course according to the book's preface) by Guenther (2005) highlights the key problem with EPS comparisons across firms. On page 465, Guenther reminds us that, "one firm may report higher earnings per share than another firm simply because it has fewer shares outstanding."

While these aforementioned MBA level financial accounting textbooks warn students about the perils of EPS comparisons across companies, two MBA level financial accounting textbooks that we reviewed did not provide this warning. Anthony, Hawkins, Merchant (2004) discuss the issue of the impact of dilutive securities on EPS and Hughes, Ayres, and Hoskin (2005) discuss the value of cross-company P/E ratio comparisons, but neither textbook provides any warning about avoiding cross-company EPS comparisons.

\section{Intermediate Accounting Textbooks}

The EPS discussion in intermediate accounting textbooks such as Keiso, Weygandt, and Warfield (2006), Nikolai, Bazley and Jones (2006), and Norton, Diamond, and Pagach (2006) usually avoid the mistake of leading students to believe that EPS comparisons across companies are useful. However, we found that they usually do not warn students to avoid these comparisons. In general, we found the discussion of EPS at the intermediate accounting level to be focused on procedural issues (like the potential dilutive impact of stock options) with very little insight provided on how financial statement users should use (or not use) the EPS information provided in the financial statements. 
By contrast, we found one intermediate accounting textbook by Revsine, Collins and Johnson (2005) that places special emphasis on the use of financial accounting information by decision-makers. This book is clear in its recommendation to avoid making EPS comparisons across companies on page 842:

EPS ignores the amount of capital required to generate the reported earnings. This is easy to show. Consider the 2005 performance of two companies: (Table is shown with figures for Company $A$ and B). Company A and Company B report identical basic EPS of \$10. But Company B needed twice as much equity capital and $50 \%$ more gross assets to attain the \$1,000,000 net income. Even though Company $A$ and $B$ report the same level of net income and EPS, Company B has a return of equity of only $5 \%$ while A's figure is $10 \%$. Company A generates more earnings from existing resources - that is, from its equity capital.

We found only one intermediate textbook (Spiceland, Sepe and Tomassini (2007)) that included phrasing that may lead students to think that EPS figures could be compared across companies. Spiceland et al. (2007, page 996) argue that:

The reasons for the considerable attention paid to earnings per share certainly include the desire to find a way to summarize the performance of business enterprises in a single number. Summarizing performance in a way that permits comparisons is difficult because the companies that report the numbers are different from one another. And yet, the desire to condense performance to a single number has created a demand for EPS information. The profession has responded with rules designed to maximize the comparability of EPS numbers by minimizing the inconsistencies in their calculation from one company to the next. Keep in mind as you study the requirements that the primary goal is comparability.

While Spiceland et al. (2007) never specifically say that you can compare EPS figures across companies, some students could reach this idea based on the above discussion. Furthermore, these authors do not warn students to avoid comparing EPS figures across companies.

\section{CONCLUSION}

Overall, we found the EPS discussion in most MBA level financial accounting textbooks to be helpful and warn students to avoid comparing EPS figures across companies. By contrast we found most intermediate accounting textbooks to be very procedural in nature with little discussion about the use of EPS in decision making and typically provide no warning about avoiding EPS comparisons across companies. But most students who take a course in financial accounting will do so at the introductory sophomore level and here we found six textbooks that incorrectly assert or imply that cross-company EPS comparisons are potentially useful. Additionally, we found that over 50\% of the undergraduate financial accounting textbooks that we examined provide no discussion at all to warn students that EPS comparisons across companies are to be avoided. On the other hand, we only found a few introductory financial accounting textbooks aimed at sophomores that provide some kind of warning about not making EPS comparisons across companies.

Financial accounting textbooks have wisely in recent years attempted to focus more on the users of financial statements. In the spirit of "continuous improvement" we suggest that some of these very fine textbooks need some fine tuning with respect to their discussion of EPS. Our accounting students need to know that EPS comparisons across companies are not useful. If cross-company comparisons are desired, this should be accomplished with ratios like the P/E ratio and ROE which can be fairly compared across companies.

\section{REFERENCES}

1. Anthony, Robert N., David F. Hawkins, and Kenneth A. Merchant. 2004. Accounting: Text and Cases. McGraw-Hill/Irwin, Boston.

2. Albrecht, W. Steve, James D. Stice, Earl K. Stice, and K. Fred Skousen. 2005. Accounting: Concepts and Applications ( $9^{\text {th }}$ ed.). South-Western College Publishers, Mason, Ohio.

3. Ainsworth, Penne and Dan Deines. 2004. Introduction to Accounting ( $3^{\text {rd }}$ ed.).McGraw-Hill/Irwin, New York. 
4. Bazley, John D and Loren A. Nikolai. 2006. Intermediate Accounting. South-Western College Publishers, Mason, Ohio.

5. Dyckman, Thomas R., Peter D. Easton, and Glenn M. Pfeiffer. 2007. Financial Accounting. Cambridge Business Publishers, Rosemont, Illinois.

6. Easton, Peter D., John J. Wild, and Robert F. Halsey. 2006. Financial Accounting forMBAs (2 ${ }^{\text {nd }}$ ed.). Cambridge Business Publishers, Rosemont, Illinois.

7. Edmonds, Thomas P., Cindy D. Edmonds, Frances M. McNair, Philip R. Olds, and Nancy W. Schneider. 2006. Fundamental Financial Accounting Concepts ( $5^{\text {th }}$ ed.). McGraw-Hill/Irwin, Boston.

8. Guenther, David A. 2005. Financial Reporting and Analysis. McGraw-Hill Companies, Inc., New York.

9. Harrison, Walter T., and Charles Horngren. 2006. Financial Accounting (6 ${ }^{\text {th }}$ ed.). Pearson Education, Inc., Upper Saddle River, New Jersey.

10. Horngren, Charles., T., Gary L. Sundem, John A. Elliot, and Donna Philbrick. 2005. Introduction to Financial Accounting (9th ed.). Prentice-Hall, Upper Saddle River, New Jersey.

11. Hughes, John S., Frances L. Ayres, Robert E. Hoskin. 2005. Financial Accounting:A Valuation Emphasis. John Wiley \& Sons, Inc., New York.

12. Ingram, Robert W., Thomas L. Albright, and Bruce A. Baldwin. 2006. Financial Accounting: Information for Decisions $\left(6^{\text {th }}\right.$ ed.). South-Western College Publishers, Mason, Ohio.

13. Kieso, Donald E., Jerry J. Weygandt, and Terry D. Warfield. 2006. Intermediate Accounting (12th ed.). John Wiley \& Sons, New York.

14. Kimmel, Paul D., Jerry, J. Weygandt, and Donald E. Kieso. 2007. Financial Accounting: Tools for Business Decision Making (4 ${ }^{\text {th }}$ ed.). John Wiley \& Sons, New York.

15. Libby, Robert, Patricia A. Libby, and Daniel G. Short. 2007. Financial Accounting (5 ${ }^{\text {th }}$ ed.). McGraw-Hill Irwin, Boston.

16. Marshall, David H., Wayne W. McManus, and Daniel F. Viele. 2007. Accounting: What the Numbers Mean ( $7^{\text {th }}$ ed.). McGraw-Hill/Irwin, Boston.

17. Needles, Belverd E. and Marian Powers. 2007. Financial Accounting ( $9^{\text {th }}$ ed.). Houghton Mifflin Company, Boston.

18. Nikolai, Loren A., John D. Bazley, Jefferson P. Jones. 2007. Intermediate Accounting. (10 ${ }^{\text {th }}$ ed.). Thomson South-Western, Mason, Ohio.

19. Norton, Curtis L., Michael A. Diamond, and Donald P. Pagach. 2006. Intermediate Accounting. Houghton Mifflin Company, Boston.

20. Philips, Fred, Robert Libby, and Patricia A. Libby. 2006. Fundamentals of Financial Accounting. McGrawHill/Irwin. Boston.

21. Porter, Gary A. and Curtis L. Norton. 2005. Financial Accounting: The Impact on Decision Makers, The Alternative to Debits and Credits ( $4^{\text {th }}$ ed.). South-Western College Publishers, Mason, Ohio.

22. Pratt, Jamie. 2006. Financial Accounting in an Economic Context (6 ${ }^{\text {th }}$ ed.). John Wiley \& Sons, New York.

23. Reimers, Jane L. 2003. Financial Accounting: A Business Process Approach. Pearson Education, Inc., Upper Saddle River, New Jersey.

24. Reimers, Jane L. 2005. Financial Accounting. Prentice Hall/Pearson Education Inc., Upper Saddle River, New Jersey.

25. Revsine, Lawrence, Daniel W. Collins, and W. Bruce Johnson. 2005. Financial Reporting and Analysis $\left(3^{\text {rd }}\right.$ ed.). Pearson/Prentice Hall, Upper Saddle River, New Jersey.

26. Solomon, Paul. 2004. Financial Accounting: A New Perspective. McGraw-Hill Companies, Inc., Boston.

27. Spiceland, J. David, James Sepe, and Lawrence A. Tomassini. 2007. Intermediate Accounting (4 ${ }^{\text {th }}$ ed.). McGraw-Hill/Irwin, Boston.

28. Stickney, Clyde P. and Roman L. Weil. 2006. Financial Accounting: An Introduction to Concepts, Methods, and Uses (11 ${ }^{\text {th }}$ ed.). South-Western, Mason, Ohio.

29. Warren, Carl S., James M. Reeve, and Philip E. Fess. 2004. Financial Accounting (9 ${ }^{\text {th }}$ ed.). South-Western College Publishers, Mason, Ohio.

30. Werner, Michael L and Kumen H. Jones. 2003. Introduction to Financial Accounting: A User Perspective ( $3^{\text {rd }}$ ed.). Prentice-Hall, Upper Saddle River, New Jersey.

31. Wild, John. J. 2005. Financial Accounting: Information for Decisions ( $3^{\text {rd }}$ ed.). McGraw-Hill/Irwin, New York. 
NOTES 